\title{
Advanced Oxidation of Segregated Streams for Effective Color Removal from Denim Processing Effluents
}

\author{
Tugba Olmez-Hanci ${ }^{1 \mathbb{D}}$, Ilke Pala-Ozkok ${ }^{1 \mathbb{D}}$, Derin Orhon ${ }^{2,3} \mathbb{D}$, Seval Sözen ${ }^{1,2, *} \mathbb{D}$ \\ 1 Environmental Engineering Department, Faculty of Civil Engineering, Istanbul Technical University, 34469 Maslak, \\ Istanbul, Turkey \\ 2 ENVIS Energy and Environmental Systems Research and Development Ltd., ITU ARI Technocity, 34469 Maslak, \\ Istanbul, Turkey \\ 3 The Science Academy, 34349 Istanbul, Turkey \\ * Correspondence: sozens@itu.edu.tr;
}

Scopus Author ID 7003783383

Received: 21.02.2021; Revised: 25.03.2021; Accepted: 30.03.2021; Published: 20.04.2021

\begin{abstract}
The study introduced footprint analysis as a new methodology and focused on differentiating wastewater streams with the highest color content and optimizing the advanced oxidation process for the segregated streams for effective color removal from denim processing. Experiments were implemented to four segregated streams rather than the entire plant effluent. A flow proportional composite mixture of segregated streams was used for color removal experiments using the advanced oxidation process with ozone and hydrogen peroxide and Fenton oxidation as other alternatives. The latter yielded the best results achieving total removal of color below visual detection limit after an optimum reaction time of 10 minutes. The Fenton oxidation process was also applied to a representative sample from the plant effluent after the physical-chemical treatment sequence, where color absorbance levels were lowered at all wavelengths below $1.0 \mathrm{~m}^{-1}$. The merit of the new footprint approach was confirmed by the results, which provided a conclusive indication that color treatment at source, implemented on selected segregated wastewater streams, presented concrete advantages over the end of pipe treatment of the overall effluent.
\end{abstract}

Keywords: color removal; denim processing; stream segregation; advanced oxidation.

(C) 2021 by the authors. This article is an open-access article distributed under the terms and conditions of the Creative Commons Attribution (CC BY) license (https://creativecommons.org/licenses/by/4.0/).

\section{Introduction}

The traditional way of wastewater management for industrial effluents prescribes an end-of-pipe approach, which would treat the overall plant effluent. While this approach may be acceptable for conventional parameters such as organic carbon (COD), suspended solids, it should be avoided to the extent possible, especially in textile plants, because it does not permit to identify and remove specific pollutants such as color at the source, without being diluted in the overall waste stream. This study specifically focused on color removal in plants manufacturing denim materials, a key branch in the textile industry, possibly with the highest market share.

Denim processing relies on a variable sequence of various steps, each utilizing different processes and chemicals; dyeing and release of dyes into the waste stream occurs only in a few of these steps. Consequently, this study defined and implemented an innovative methodology of an experimental in-plant assessment, which uncovered the color footprint, i.e., the color fingerprint of all individual wastewater streams. Recently, pollution footprints were suggested 
as an effective approach to identify the source and the relative magnitude of specific pollutants of interest among different steps of industrial activities [1]. Indexes were suggested for a more effective footprint assessment [2,3]. Recently, this approach was successfully implemented to manage the wastewater of a textile dye house handling different types of fabrics $[4,5]$ and for sludge generated in a municipal wastewater treatment plant for the optimization of net useful energy [6].

Color is one of the most easily recognized properties of wastewaters because it directly addresses visual perception. Therefore, it immediately raises aesthetic concerns, and it is usually interpreted as a sign of serious pollution. Sewage has an inherent brown color usually associated with the mixture of organics it contains [7]. However, the major color problem is mostly related to dyeing and washing operations in industrial activities, especially in textile operations, where a fraction of the dye is not exhausted on the fiber of fabric and released into the effluent and causes deep color [8]. Since the presence of a small fraction of dye remains visible, even after a high dilution ratio, discharge of these effluents decreases the beneficial aesthetic use of streams and other water bodies $[9,10]$. Aside from aesthetic effects, most dyes with intricate aromatic structures resist biodegradation during treatment and in the environment; if not properly removed, dyes may significantly reduce photosynthetic activity in aquatic environments as they impair light penetration [11].

Generally, the textile generates high volumes of wastewater in the range of 20-380 $\mathrm{m}^{3} /$ ton of product, depending on the type of fiber/fabric, applied processes, and technologies [12-14]. Textile activities also consume a large variety of dyes and processing chemicals. It is generally estimated that a significant fraction of chemicals are wasted, and around 10 to $30 \%$ of the dye is lost to the effluent during the dyeing process depending on the fixation ratios fixation in the production processes $[15,16]$. These facts have triggered efforts to minimize the use of water and chemicals and encouraged reuse options within the production steps $[17,18]$.

Over the years, extensive research effort was devoted to test and develop effective technology for color removal, which may be briefly reviewed in four different categories: (i) physical and/or physicochemical methods such as adsorption, chemical settling, ion exchange, etc. [2, 19-25]. This group defines the traditional but continuing studies on color removal practice, mainly focusing on coagulation/flocculation. The general consensus is that a particular coagulant is only suitable for a certain type of dye. The study of [1] is interesting in the sense that it tested polygoskite clay as a strong adsorbent to remove indigo dye from synthetic wastewater; the adsorbed dye was used to synthesize the Maya Blue pigment, a valuable product. (ii) Advanced oxidation processes (AOP)s, such as ozonation, $\mathrm{H}_{2} \mathrm{O}_{2} / \mathrm{UVC}$ photochemical oxidation with hydrogen peroxide), Fenton, photo-Fenton, anodic oxidation, and electro-Fenton [26-34]. In a study, Fenton oxidation was tried before the activated sludge process, and chromium-induced advanced oxidation was recommended as a novel process, which does not require additional metal $\left(\mathrm{Fe}^{2+}\right)$ supply [35]. (iii) Biological processes based on pure and mixed cultures operated in aerobic and/or anaerobic conditions [36-39]. Biological processes were even tested as a pre-treatment in a combined process configuration involving coagulation/flocculation and chemical settling; electrochemical oxidation steps for effective color removal [40, 41]. (iv) Membrane processes [42-44]. This application involved ultrafiltration (UF) and reverse osmosis (RO) after biological treatment, essentially for reuse purposes. The outcome of the extensive information available for color removal while testing all possible processes, is mostly case-specific and does not offer a generally applicable guideline for this purpose. 
In denim production, dyeing and washing processes are the main sources of wastewater generation. Wastewater includes high levels of indigo blue $\left(\mathrm{C}_{16} \mathrm{H}_{10} \mathrm{~N}_{2} \mathrm{O}_{2}\right)$, a dye belonging to the vat group, and alkaline chemicals. Indigo blue is a synthetic organic dye, and it is considered recalcitrant due to its complex chemical structure [14, 21, 45]. Approximately 30\% of the applied indigo blue dye remains unfixed and ends in the wastewater [21]. Wastewater containing indigo blue dye also includes a very high level of suspended solids due to pumice stone used in the bleaching process, a high amount of chemical oxygen demand (COD), dissolved solids, and a distinct dark blue color [46-48]. Earlier works mostly investigated the biodegradation characteristics and applicable treatment technologies of denim effluents [37, 49-51]. A few recent studies also evaluated color removal, using both physicochemical and advance oxidation technologies, but they focused on effective color removal from the entire plant effluent, prescribing an end-of-pipe approach [52, 53].

Thus, the study aimed to identify wastewater streams with the highest color content and optimize the advanced oxidation process for the segregated streams for effective color removal from denim processing. For this purpose, an innovative approach for the assessment of the color footprint of the plant was adopted, which involved a full inventory of wastewater and polluting sources in the plant. Advanced oxidation experiments using ozonation and Fenton oxidation were carried out on segregated wastewater streams differentiated based on the color footprint. Results indicated effective color removal and offered a new perspective for evaluating wastewater reuse potential.

\section{Materials and Methods}

\subsection{Research rationale.}

This study was carried out within a large project organized for the optimal management of wastewater streams generated in a denim plant located in Çorlu, Turkey. The first part of the project was focused on a detailed assessment of pollution footprint, covering all operational steps with a major contribution to the production scheme of the plant.

This database indicated all individual wastewater streams with selected pollutants and color and identified the sources with the highest impact on the color level in the wastewater. Representative wastewater samples were taken from the four segregated sources with the highest color input and analyzed for major parameters. The same analyses were also conducted on their flow-proportional composite mixture.

Then, a complete evaluation of the plant effluent was carried out in terms of its color content. For this purpose, daily composite samples were collected for 30 days, during the period of 19.02.2018 - 05.04.2018, and analyzed for all color components. For each color component, all samples' results were evaluated in terms of a statistical distribution yielding percentile values of corresponding measurements. Results were compared with those associated with four segregated sources with the highest color input.

Samples characterizing the four selected segregated sources and a representative sample from the plant effluent were subjected to laboratory-scale evaluation for color removal. Oxidation with ozone and hydrogen peroxide $\left(\mathrm{H}_{2} \mathrm{O}_{2}\right)$ and Fenton oxidation were tested on the flow-proportional composite mixture of segregated streams. Based on best removals achieved, Fenton oxidation alone was tested using the plain settling effluent and the effluent physicalchemical treatment sequence applied to composite plant effluent. A schematic description of the adopted experimental program is displayed in Figure 1. 


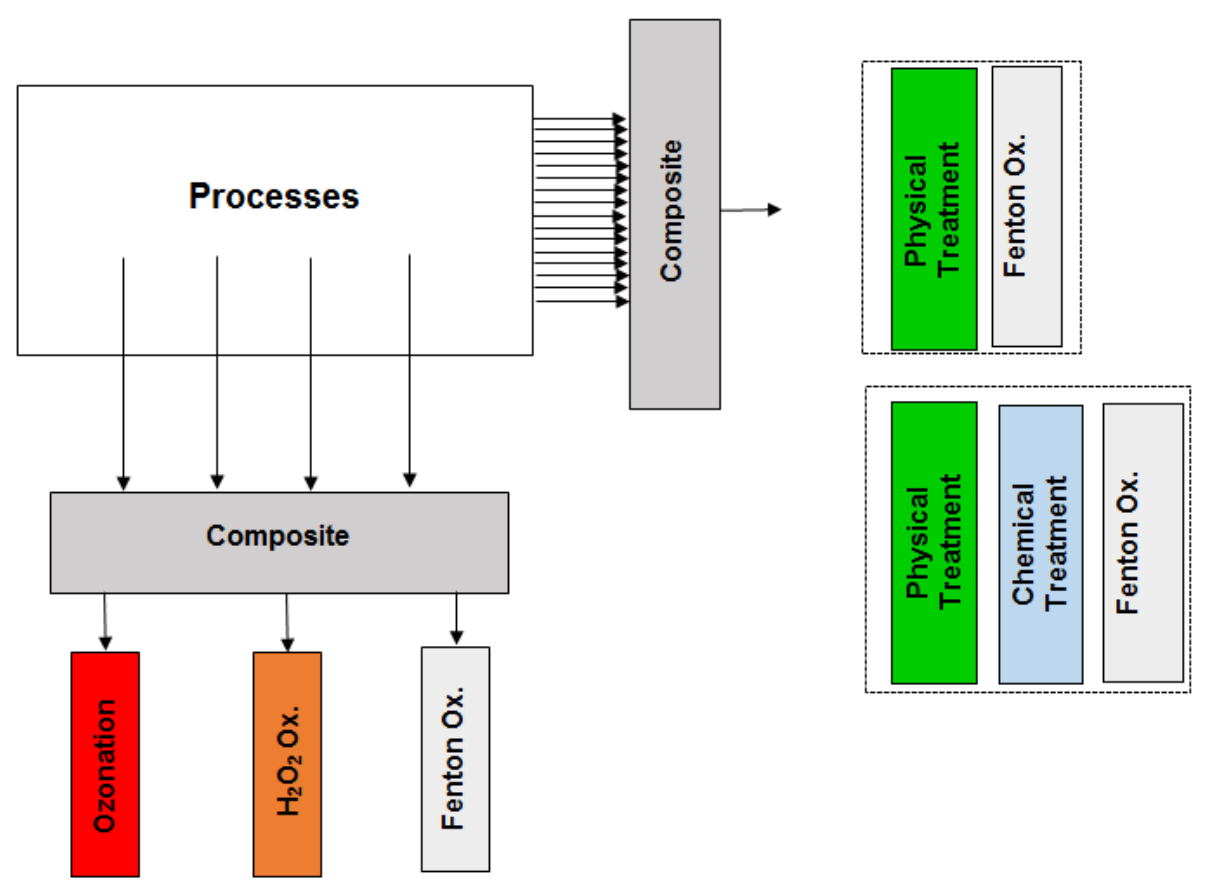

Figure 1. Schematic display of the experimental program.

\subsection{Experimental setup.}

Wastewater samples were oxidized by ozone in a borosilicate glass column with a volume of $1500 \mathrm{~mL}$. The effective volume of the reactor was $1000 \mathrm{~mL}$. For the oxidation process, the $\mathrm{O}_{3}+$ air mixture was supplied to the reactor's bottom at a flow rate of $1 \mathrm{~L} / \mathrm{min}$ through a coarse sintered gas dispersion disc. An Arcbull Meo-20 model ozone generator, with a capacity between $5-25 \mathrm{mg} / \mathrm{L}$, was used to obtain ozone from oxygen. Oxygen was separated from air with a Health time OC-5 oxygen concentrator. The ozone generator was connected to the reactor using teflon tubing. A typical run was initially started by filling with wastewater; then it proceeded with continuous ozonation in a semi-batch mode concerning ozone gas feeding. Samples were taken at regular time intervals from the reactor and analyzed for color, $\mathrm{COD}$, and $\mathrm{pH}$. Ozone concentrations were measured via iodometry [54], and the utilized ozone doses after ozonation experiments were determined using the difference between the inlet and the off-gas ozone concentrations. Ozone treatment was carried out by passing ozone gas through a $750 \mathrm{~mL}$ sample volume at 5,10, and 15-minute exposure times. The ozone dosage was adjusted to $45 \mathrm{mg} / \mathrm{min}$ in the experiments. Sample volume was set as $250 \mathrm{~mL}$, and the initial $\mathrm{H}_{2} \mathrm{O}_{2}$ concentration was calculated as $7140 \mathrm{mg} / \mathrm{L}$. At the original $\mathrm{pH}$ of 5.89 of the sample, the effect of $\mathrm{H}_{2} \mathrm{O}_{2}$ oxidation was observed after 5, 10, 15, and 30 minutes.

Fenton oxidation experiments were conducted in the range of 5-30 minutes in parallel $250 \mathrm{~mL}$ glass beakers that were continuously stirred. The stoichiometric oxygen equivalent of the wastewater, computed based on the initial COD concentration $\left(\mathrm{H}_{2} \mathrm{O}_{2}=2.12 x C O D\right)$, was used to determine the initial $\mathrm{H}_{2} \mathrm{O}_{2}$ concentration [55]. $\mathrm{Fe}^{2+}$ catalyst was fed to the solution while the parallel reactors (beakers) were continuously stirred at $100 \mathrm{rpm}$ from a $\mathrm{FeSO}_{4} \cdot 7 \mathrm{H}_{2} \mathrm{O}$ stock solution (10\%w/v, Merck).

In the segregated stream experiments, the initial dosage of $2352 \mathrm{mg} / \mathrm{L}$ of $\mathrm{Fe}^{2+}$ dropped the original $\mathrm{pH}$ of the sample from 5.89 to 5.20 , which was further dropped to 2.81 after the addition of $7140 \mathrm{mg} / \mathrm{L}$ of $\mathrm{H}_{2} \mathrm{O}_{2}(35 \% \mathrm{w} / \mathrm{w})$ to approach the optimum operational $\mathrm{pH}$ of around 3.0. The molar ratio of $\mathrm{H}_{2} \mathrm{O}_{2}: \mathrm{Fe}(\mathrm{II})$ was adjusted to $5: 1$. 
A similar procedure was adopted when evaluating plain settled and chemically treated effluents in the plant effluent surveys: The experiment was started at an initial $\mathrm{pH}$ of 6.74 for plain settling effluent; the sample's $\mathrm{pH}$ was adjusted to 3.0 by adding $423 \mathrm{mg} / \mathrm{L} \mathrm{of} \mathrm{Fe}^{2+}$ and $1284 \mathrm{mg} / \mathrm{L}$ of $\mathrm{H}_{2} \mathrm{O}_{2}$. In the experiments conducted on chemically treated effluent with an initial $\mathrm{pH}$ of 4.1 , the $\mathrm{pH}$ was reduced to 3.0 with the addition of $370 \mathrm{mg} / \mathrm{L}$ of $\mathrm{Fe}^{2+}$ and $1122 \mathrm{mg} / \mathrm{L}$ of $\mathrm{H}_{2} \mathrm{O}_{2}$. The experiments were terminated by increasing the samples' $\mathrm{pH}$ to the range of 7.0-7.5 with $6 \mathrm{~N} \mathrm{NaOH}$ to ensure the formation of iron hydroxide flocs, which were removed by filtration using $0.45 \mu \mathrm{m}$ membrane filters.

All experiments were carried out duplicated at room temperature $\left(20 \pm 1^{\circ} \mathrm{C}\right)$; average values were taken when presenting the results.

\subsection{Analytical measurements.}

Color measurements were carried out using a spectrophotometer (Hach Lange DR 5000), both as absorbance at different wavelength 436, 525, $620 \mathrm{~nm}$, and Pt-Co units [56]. The COD analyses were conducted by open reflux-titration according to the procedure defined in ISO 6060 method [57]. All other analyses were conducted following the procedures defined in Standard Methods [56]. $\mathrm{pH}$ values were measured with a digital $\mathrm{pH}$ meter (Thermo Scientific Orion Star A211, Waltham, MA). Analyses involved at least triplicate measurements: additional measurements were performed when necessary until the observed variance decreased below $5 \%$.

\subsection{Statistical analyses.}

The probability distribution of different color levels measured in 30 plant effluent samples was established using a simple approach, which also proved successful in other similar studies [58, 59]. Essentially, the method relied on arranging measured color, $\mathrm{C}$, from the smallest to the highest and estimated $\mathrm{pC}_{\mathrm{i}}$ as:

$$
p C i=i / n+i
$$

Where, $\mathrm{pC}_{\mathrm{i}}$ is the probability of observing the $\mathrm{C}$ value equal or smaller than $\mathrm{C}_{\mathrm{i}}$; $\mathrm{C}_{\mathrm{i}}$, the color level in the $\mathrm{i}^{\text {th }}$ rank; and $\mathrm{n}$, the total number of observations. Then, $\mathrm{pC}_{\mathrm{i}}$ values were plotted using a probability scale to yield the 50 and 70 percentile levels for different color measurements.

\section{Results and Discussion}

\subsection{Pollution profile.}

The first part of the experimental work started with a detailed survey of the pollution profile for the plant; it was conducted on 16 different processes representing the core of the production scheme in the plant. Different processes included 3 to 11 successive steps, and the analytical survey covered each and every existing step taking part in the processes. The results give a clear indication that the utilization frequency of each process greatly varies depending on the scheduled activities of the plant. Consequently, the wastewater flow fluctuates between $3600 \mathrm{~m}^{3} /$ year and $196000 \mathrm{~m}^{3} /$ year, and the COD load from $3400 \mathrm{~kg} /$ year to $265000 \mathrm{~kg} / \mathrm{year}$ between different processes. The survey enabled us to compute average values of 
approximately $2000 \mathrm{~m}^{3} /$ day and $1200 \mathrm{mg} / \mathrm{L}$ for the daily flow rate and the overall plant effluent's COD content.

Color contents of different steps in all processes were also assessed. Obviously, color measured in terms of Pt-Co unit and/or absorbance at different wavelengths is not amenable to mass balance. Instead, measurements indicated four segregated wastewater streams with much higher color input compared to others. Representative waste wastewater samples were taken from the four sources with the highest color input for further evaluation in lab-scale experiments. Table 1 summarizes major characteristics of these four segregated wastewater streams and their flow-proportional mixture; it clearly shows that the selected wastewater streams and the composite mixture indeed represent highly colored and strong effluents with an average COD content of $3380 \mathrm{mg} / \mathrm{L}$, approximately three times higher than the average value of $1200 \mathrm{mg} / \mathrm{L}$ in the plant effluent.

Table 1. Major characteristics of the four selected wastewater steam and their mixture.

\begin{tabular}{l|c|c|c|c|c|c|c} 
Process & $\mathbf{p H}$ & Total COD & Soluble COD & \multicolumn{5}{|c}{ Color } \\
\cline { 5 - 8 } & & $(\mathbf{m g} / \mathbf{L})$ & $(\mathbf{m g} / \mathbf{L})$ & $\mathbf{P t - C o}$ & $\mathbf{4 3 6} \mathbf{~ n m}(\mathbf{m}-\mathbf{1})$ & $\mathbf{5 2 5} \mathbf{~ n m}(\mathbf{m}-\mathbf{1})$ & $\mathbf{6 2 0} \mathbf{~ n m}(\mathbf{m}-\mathbf{1})$ \\
\hline Heavy stone washing & - & 6150 & 3330 & 3240 & 105.6 & 114 & 190 \\
\hline Dark stone washing & - & 4670 & 2770 & 2530 & 177.2 & 163.6 & 226.4 \\
\hline Rinse washing/pre-washing & - & 2270 & 1350 & 4870 & 123.6 & 133.2 & 133.6 \\
\hline Hot stone washing & - & 1580 & 1100 & 1310 & 42.4 & 55.6 & 100.4 \\
\hline Composite & 5.89 & 3380 & 2440 & 2340 & 64 & 73.2 & 115.2
\end{tabular}

Furthermore, the color content of the plant effluent was also assessed in 30 different daily composite samples representing an observation period of 45 days. The plant effluent always involved a high color level, which was determined using both Pt-Co units and absorbance at 436, 525, and $620 \mathrm{~nm}$. Figure 2 reflects the statistical distribution of color measurements. Similar statistical evaluations were also carried out for other major parameters. As displayed in the figure, the distribution of all color measurements exhibited significant daily variations depending on the plant's daily production activities. Corresponding 50 percentile values $\left(\mathrm{C}_{50}\right)$ for Pt-Co, $436 \mathrm{~nm}, 525 \mathrm{~nm}$ and $620 \mathrm{~nm}$ were determined as 517, $17.46 \mathrm{~m}^{-1}, 21.14$ $\mathrm{m}^{-1}$ and $26.64 \mathrm{~m}^{-1}$, respectively. These values were identified as $654,25.85 \mathrm{~m}^{-1}, 27.09 \mathrm{~m}^{-1}$ and $40.45 \mathrm{~m}^{-1}$ for 70 percentile values $\left(\mathrm{C}_{70}\right)$. Comparison of the statistical color levels in the plant effluent with those given in Table 1 reflect exceedingly high color levels of the selected four wastewater streams both in terms of Pt-Co unit and absorbance as three wavelengths.
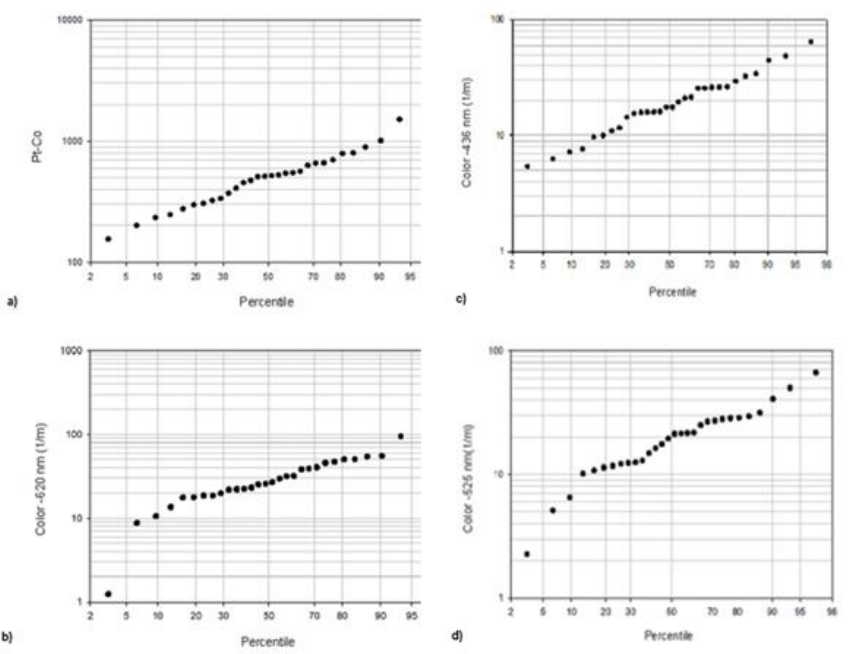

Figure 2. Statistical distribution of color measurements as (a) Pt-Co units (b) absorbance at 620nm (c) absorbance at $435 \mathrm{~nm}(\mathrm{~d})$ absorbance at $525 \mathrm{~nm}$. 


\subsection{Color removal experiments.}

\subsubsection{Segregated wastewater streams.}

The first part of the experiments on color removal was started with the flowproportional composite mixture of the segregated wastewater streams. Relevant characteristics of the composite mixture were outlined in Table 1. Experiments on color removal involved ozone treatment, $\mathrm{H}_{2} \mathrm{O}_{2}$ oxidation, and Fenton oxidation.

In the first step, ozone treatment was carried out at 5, 10, and 15-minute exposure times. After $675 \mathrm{mg}$ of ozone dosage in 15 minutes, the off-gas ozone was measured as $482 \mathrm{mg}$, corresponding to $193 \mathrm{mg}$ of ozone utilized in the experiment. As indicated by the results summarized in Table 2, ozone treatment could only yield partial color removal; even after 15 min exposure time, color reduction remained at $46 \%$ in Pt-Co units and $36 \%$ as absorbance at $436 \mathrm{~nm}$. However, reductions in absorbance at $525 \mathrm{~nm}$ and $620 \mathrm{~nm}$ reached $86 \%$ and $94 \%$, respectively. It is noteworthy to mention that the intense blue color of the sample faded away, and it was substituted by a light brown-yellow color (Figure S1).

Table 2. Color removal performance of ozone oxidation on the mixture of segregated wastewater streams.

\begin{tabular}{l|c|c|c|c|c|c}
\multirow{2}{*}{ Time (min) } & \multirow{2}{*}{ Total COD $(\mathbf{m g} / \mathbf{L})$} & \multirow{2}{*}{ Soluble COD $(\mathbf{m g} / \mathbf{L})$} & \multicolumn{5}{|c}{ Color } \\
\cline { 4 - 7 } & & & $\mathbf{P t}-\mathbf{C o}$ & $\mathbf{4 3 6} \mathbf{~ n m}\left(\mathbf{m}^{-\mathbf{1}}\right)$ & $\mathbf{5 2 5} \mathbf{~ n m}\left(\mathbf{m}^{-\mathbf{1}}\right)$ & $\mathbf{6 2 0} \mathbf{~ n m}\left(\mathbf{m}^{-\mathbf{1}}\right)$ \\
\hline $\mathbf{0}$ & 3380 & 2440 & 2340 & 64 & 73.2 & 115.2 \\
\hline $\mathbf{5}$ & 3240 & 2430 & 1870 & 58.8 & 23.2 & 20.0 \\
\hline $\mathbf{1 0}$ & 3170 & 2590 & 1520 & 49.2 & 13.2 & 8.4 \\
\hline $\mathbf{1 5}$ & 3180 & 2600 & 1260 & 41.2 & 10.0 & 7.2
\end{tabular}

The next step involved $\mathrm{H}_{2} \mathrm{O}_{2}$ oxidation started with an initial concentration of 7170 $\mathrm{mg} / \mathrm{L}$ calculated as the theoretical equivalent of $2.12 \mathrm{COD}$. The experiments indicated that $\mathrm{H}_{2} \mathrm{O}_{2}$ remained ineffective during all the reaction periods $(5,10,15$, and 30 minutes). As shown in Table 3, the achieved color removal was only 5\% as Pt-Co units and stayed in the range of 6-19\% as absorbance at different wavelengths.

The Fenton process is oxidation by $\mathrm{H}_{2} \mathrm{O}_{2}$ and $\mathrm{Fe}^{2+}$. The reaction times for Fenton oxidation were again selected in the range of 5 to 30 minutes. As displayed in Table 4, the start of the experiment reflected the very high color levels in the mixture of segregated wastewater streams, namely $2340 \mathrm{Pt}-\mathrm{Co}$ units together with $64 \mathrm{~m}^{-1}, 73.2 \mathrm{~m}^{-1}$, and $115.2 \mathrm{~m}^{-1}$ absorbance levels at $436 \mathrm{~nm}, 525 \mathrm{~nm}$, and $620 \mathrm{~nm}$, respectively; a 5 minutes contact time did not prove sufficient, as the color removal remained limited to the range of $69-89 \%$. However, 10 minutes of contact time induced very effective color reduction down to $33 \mathrm{Pt}-\mathrm{Co}$ and below $1.0 \mathrm{~m}^{-1}$ for absorbance at $436 \mathrm{~nm}$ and $620 \mathrm{~nm}$. The optimum contact time for absorbance at $525 \mathrm{~nm}$ was 15 minutes, also securing color reduction down to $0.68 \mathrm{~m}^{-1}$. As also displayed in Figure S2, the color disappeared completely below the visual detection limit after an optimum reaction time of 10 minutes.

\subsubsection{Plant effluent.}

The merit of an integrated physical-chemical scheme as an appropriate pre-treatment for denim processing wastewaters was investigated in the earlier part of the study; it indicated that the selected pre-treatment, first involving plain settling followed by chemical treatment, was quite effective in prov adjusting the major parameters in wastewater to a level suitable for biological treatment [52]. In this context, color removal from the overall plant effluent was also tested to offer a benchmarking against a selection of segregated wastewater streams. Fenton 
oxidation, which proved to be the most effective advanced oxidation method, in this case, was applied to the effluent sample after (i) plain settling and (ii) chemical treatment. Performance of physical-chemical treatment, i.e., effluent characteristics after plain settling and chemical treatment, are summarized in Table 4, which shows quite a limited color reduction, despite significant COD removals achieved through these pre-treatment steps. Therefore, the biological treatment units will receive an influent with a strong color level, which would be likely to by-pass this treatment step and persist in the effluent without an additional color removal mechanism.

Table 3. Color removal performance of $\mathrm{H}_{2} \mathrm{O}_{2}$ and Fenton oxidation on the mixture of segregated wastewater streams.

\begin{tabular}{|c|c|c|c|c|c|c|c|c|c|c|c|}
\hline \multirow[b]{3}{*}{$\begin{array}{l}\text { Time } \\
(\mathrm{min})\end{array}$} & \multirow[b]{3}{*}{$\begin{array}{c}\text { Total } \\
\text { COD } \\
(\mathrm{mg} / \mathrm{L})\end{array}$} & \multicolumn{5}{|c|}{$\mathrm{H}_{2} \mathrm{O}_{2}$ Oxidation } & \multicolumn{5}{|c|}{ Fenton Oxidation } \\
\hline & & \multirow[b]{2}{*}{$\begin{array}{l}\text { Soluble COD } \\
(\mathrm{mg} / \mathrm{L})\end{array}$} & \multicolumn{4}{|c|}{ Color } & \multirow[b]{2}{*}{$\begin{array}{c}\text { Soluble } \\
\text { COD } \\
(\mathrm{mg} / \mathrm{L})\end{array}$} & \multicolumn{4}{|c|}{ Color } \\
\hline & & & Pt-Co & $\begin{array}{c}436 \\
\mathrm{~nm} \\
\left(\mathrm{~m}^{-1}\right)\end{array}$ & $\begin{array}{c}525 \mathrm{~nm} \\
\left(\mathrm{~m}^{-1}\right)\end{array}$ & $\begin{array}{c}620 \mathrm{~nm} \\
\left(\mathrm{~m}^{-1}\right)\end{array}$ & & Pt-Co & $\begin{array}{c}436 \mathrm{~nm} \\
\left(\mathrm{~m}^{-1}\right)\end{array}$ & $\begin{array}{c}525 \mathrm{~nm} \\
\left(\mathrm{~m}^{-1}\right)\end{array}$ & $\begin{array}{c}620 \mathrm{~nm} \\
\left(\mathrm{~m}^{-1}\right)\end{array}$ \\
\hline 0 & 3380 & 2440 & 2340 & 64 & 73,2 & 115,2 & 2440 & 2340 & 64 & 73,2 & 115,2 \\
\hline 5 & - & 2470 & 2030 & 54,6 & 56,8 & 82,6 & 825 & 675 & 19,96 & 14,28 & 13,6 \\
\hline 10 & - & 2515 & 2250 & 60,6 & 63,8 & 93,8 & 660 & 33 & 0,76 & 4,56 & 0,1 \\
\hline 15 & - & 2315 & 2300 & 61,8 & 65,4 & 96,4 & 450 & 55 & 1,8 & 0,68 & 0,21 \\
\hline 30 & - & 2250 & 2230 & 60 & 63,6 & 93,4 & 470 & 73 & 2,28 & 1,08 & 0,56 \\
\hline
\end{tabular}

Table 4. Performance of plain settling and chemical treatment on the plant effluent.

\begin{tabular}{|c|c|c|c|c|c|c|}
\hline \multirow{2}{*}{$\begin{array}{l}\text { Characteristics of the } \\
\text { wastewater }\end{array}$} & \multirow{2}{*}{$\begin{array}{c}\text { Total COD } \\
\quad(\mathrm{mg} / \mathrm{L})\end{array}$} & \multirow{2}{*}{$\begin{array}{l}\text { Soluble COD } \\
\quad(\mathrm{mg} / \mathrm{L})\end{array}$} & \multicolumn{4}{|c|}{ Color } \\
\hline & & & Pt-Co & $436 \mathrm{~nm}\left(\mathrm{~m}^{-1}\right)$ & $525 \mathrm{~nm}\left(\mathrm{~m}^{-1}\right)$ & $620 \mathrm{~nm}\left(\mathrm{~m}^{-1}\right)$ \\
\hline Raw wastewater & 1250 & 680 & 970 & 33.2 & 37.6 & 56.4 \\
\hline Plain settled & 790 & 630 & 870 & 25.6 & 31.2 & 55.2 \\
\hline Chemical treated & 485 & 370 & 316 & 8.16 & 10.4 & 18.24 \\
\hline
\end{tabular}

Fenton oxidation's performance on the effluent of plain sedimentation is quite impressive, as given in Table 5: Soluble COD drops down to $180 \mathrm{mg} / \mathrm{L}$ and $130 \mathrm{mg} / \mathrm{L}$ after reactions times of $5 \mathrm{~min}$. and $30 \mathrm{~min}$., respectively. Color is reduced to 58 (93\% removal) and 37 (96\% removal) Pt-Co units at the end of the same reaction periods. A 30 min reactor phase lowers absorbance level at all wavelengths below $1.0 \mathrm{~m}^{-1}$. The color was lowered below the visual detection limit after a reaction time of $5 \mathrm{~min}$.

Table 5. Color removal from plant effluent after plain settling with Fenton oxidation.

\begin{tabular}{|c|c|c|c|c|c|c|c|}
\hline \multirow{2}{*}{$\begin{array}{l}\text { Time } \\
(\min )\end{array}$} & \multirow[b]{2}{*}{ pH } & \multirow{2}{*}{$\begin{array}{c}\text { Total COD } \\
(\mathrm{mg} / \mathrm{L})\end{array}$} & \multirow{2}{*}{$\begin{array}{l}\text { Soluble COD } \\
(\mathrm{mg} / \mathrm{L})\end{array}$} & \multicolumn{4}{|c|}{ Color } \\
\hline & & & & Pt-Co & $436 \mathrm{~nm}\left(\mathrm{~m}^{-1}\right)$ & $525 \mathrm{~nm}\left(\mathrm{~m}^{-1}\right)$ & $620 \mathrm{~nm}\left(\mathrm{~m}^{-1}\right)$ \\
\hline 0 & 6.74 & 790 & 630 & 870 & 25.6 & 31.2 & 55.2 \\
\hline 5 & 3.0 & - & 180 & 56 & 1.64 & 2.88 & 1.40 \\
\hline 10 & 3.0 & - & 195 & 34 & 1.12 & 1.84 & 0.68 \\
\hline 15 & 3.0 & - & 185 & 48 & 1.36 & 1.04 & 0.88 \\
\hline 30 & 3.0 & - & 130 & 37 & 1.04 & 0.80 & 0.64 \\
\hline
\end{tabular}

In the next phase, the effluent of chemical treatment carried out with $1.0 \mathrm{~mL} / \mathrm{L}$ of PE and $1.0 \mathrm{~mL} / \mathrm{L}$ of liquid PAC, was used for Fenton oxidation to achieve color removal. Table 4 summarized related characteristics of the chemical treatment effluent. At the start of the experiment, the initial color was only $12-15 \%$ of the levels ascertained in the mixture of segregated streams due to substantial dilution within the overall plant effluent. Fenton oxidation's performance was essentially very similar, reducing remaining color levels below $1.0 \mathrm{~m}^{-1}$ absorbance, i.e., below the visual detection limit, after a 10 minutes contact time. A reaction time of $30 \mathrm{~min}$ reduced the soluble COD down to $110 \mathrm{mg} / \mathrm{L}$, a level hard to obtain by 
biological treatment due to soluble residual COD and metabolic products [60]. Additional information about this test was reported elsewhere [53].

First of all, this study advocated a new methodology for effective color control in denim processing effluents. Extensive research efforts testing different advanced oxidation techniques on a large spectrum of dyes have so far failed to provide a sustainable answer to solving the color problem in textile wastewaters. The reason because this failure is quite simple: (i) It generally involved an end-of-pipe approach on the overall plant, which dilutes the colored streams; (ii) the advanced oxidation techniques as a pre-treatment the biological stage before remained partly effective due to the interference of organic matter; (iii) biological treatment suffered from adverse effects of dyestuff on the microbial culture; (vi) advanced oxidation was mostly applied as a post-treatment on the biological treatment effluent.

In this context, the study advocated a novel approach of applying effective color removal on segregated waste streams carrying the major fraction of color as a pre-treatment before biological removal of organic matter. It essentially involved segregation of wastewater streams generated by dyeing operations in the plant and treating these streams as a source, before being mixed with and diluted in the overall effluent. This methodology is sustainable and equally applicable to all industrial applications and all selected pollutants. Denim processing and finishing involve a complex array of steps and operations, each generating wastewaters with different characteristics. Therefore, end of pipe inspection of wastewater quality may prove meaningless and even misleading for controlling key pollutants such as color.

Consequently, the study adopted a much more sustainable in-plant analysis approach, which created a database covering all production steps and identifying all processes using dyes. Essentially this analysis yielded water and pollutant footprinting for the plant. The footprint approach that was used in a previous study essentially identified the relative magnitude of parameters such as water use and organic load (COD) in each production step in the plant [4]. A numerical/quantitative footprint cannot be established for the color, which is measured in terms of indexes such as absorbance, but these measurements enabled to identification and segregate of the four major wastewater streams to be treated at the source as indicated in Table 1 .

The data on chemical use for color removal from the selected segregated streams allows a comparison with the case where the same processes would be applied to the overall plant effluent with an end-or pipe approach. They indicate a chemical reduction of $20-22 \%$ for Fenton oxidation in favor of segregated stream treatment. Obviously, an economic feasibility study is well beyond the study's scope because it highly depends on the specific site's characteristics. It involves several factors such as dyes used in the manufacturing processes, type of treatment units, energy and personnel costs, etc. Nevertheless, the comparison of chemical use may be accepted as a reliable yardstick for the merit of stream segregation for color removal because the end of pipe treatment would necessitate a much larger footprint for the same treatment steps, with similarly higher costs for auxiliary factors.

Furthermore, the database derived from the in-plant analysis detected all dyeing operations involving different dyestuff, such as direct, sulfur, acid, reactive dyes aside from the common indigo dye, so that the experimental color removal options tested real-case scenarios. This approach should be contrasted from most studies in the field, which were conducted either on a specific dye, using synthetic wastewater, or used effluents without specifying the textile 
facility's characteristics that generated it and applied several processes for color removal on a trial and error basis.

\section{Conclusions}

The study's main message was to advocate and experimentally test a new approach of looking inside the plant, i.e., the footprint approach allowing a thorough analysis of selected key pollutants for defining and optimizing the sustainable wastewater management strategy.

The significance and the merit of this new approach were underlined by the results of the study. In fact, they offered conclusive experimental evidence that Fenton oxidation was the most suitable advanced oxidation process for achieving complete color removal at source from selected segregated waste streams with the highest color content in denim processing effluents.

Color treatment at source presented distinct technical and economic advantages over the end of pipe treatment of the overall effluent: Complete color removal from segregated waste streams by Fenton oxidation could be achieved with approximately $20 \%$ of chemicals that would be spent when the entire flow of plain settling effluent was treated for the same purpose. This ratio was slightly increased to $22 \%$ compared to the chemicals when the Fenton oxidation was applied to the entire chemical settling effluent flow. Furthermore, the separate treatment of segregated flows also benefits from advanced treatment of dyeing effluents for onsite reuse by suitable technologies.

\section{Funding}

This study was supported by Istanbul Teknik Üniversitesi (Scientific Research Fund of Istanbul Technical University, grant number: 41439). The funders had no role in the study's design, in the collection, analyses, or interpretation of data, in the writing of the manuscript, or in the decision to publish the results.

\section{Acknowledgments}

The authors are grateful for the contribution of Ş1k Makas Giyim San. Tic. A.S. for supplying the wastewater from the plant.

\section{Conflicts of Interest}

The authors declare no conflict of interest.

\section{References}

1. Wambuguh, D.; Chianelli, R.R. Indigo dye waste recovery from blue denim textile effluent: a by-product synergy approach. New J Chem 2008, 32, 2189-94, https://doi.org/10.1039/B806213G.

2. Al-Ghouti, M.A.; Khraisheh, M.A.; Allen, S.J.; Ahmad, M.N. The removal of dyes from textile wastewater: a study of the physical characteristics and adsorption mechanisms of diatomaceous earth. J Environ Manage 2003, 69, 229-38, https://doi.org/10.1016/j.jenvman.2003.09.005.

3. Athey, S.N.; Adams, J.K.; Erdle, L.M.; Jantunen, L.M.; Helm, P.A.; Finkelstein, S.A.; Diamond, M.L. The Widespread Environmental Footprint of Indigo Denim Microfibers from Blue Jeans. Environmental Science \& Technology Letters 2020, 7, 840-847, https://doi.org/10.1021/acs.estlett.0c00498.

4. Sözen, S.; Dulkadiroglu, H.; Yucel, A. Begum, Insel, G.; Orhon D. Pollutant footprint analysis for wastewater management in textile dye houses processing different fabrics. J Chem Technol Biot 2019a, 94, 1330-40, https://doi.org/10.1002/jctb.5891.

5. Luo, Y.; Song, K.; Ding, X.; Wu, X. Environmental sustainability of textiles and apparel: A review of evaluation methods. Environmental Impact Assessment Review 2021, 86, https://doi.org/10.1016/j.eiar.2020.106497. 
6. Sözen, S.; Karaca, C.; Alli, B.; Orhon, D. Sludge footprints of municipal treatment plant for the management of net useful energy generation beyond energy neutrality. J of Clean Prod 2019b, 215, 1503-1515, https://doi.org/10.1016/j.jclepro.2019.01.080.

7. Orhon, D.; Sözen, S.; Ubayo, E. Assessment of nitrification-denitrification potential of Istanbul domestic wastewaters. Water Sci Technol 1994, 30, 21-30, https://doi.org/10.2166/wst.1994.0249.

8. Manenti, D.R.; Soares, P.A.; Silva, T.F.; Módenes, A.N.; Espinoza-Quiñones, F.R.; Bergamasco, R.; Boaventura, R.A.; Vilar, V.J. Performance evaluation of different solar advanced oxidation processes applied to the treatment of a real textile dyeing wastewater. Environ Sci Pollut Res 2015, 22, 833-845, https://doi.org/10.1007/s11356-014-2767-1.

9. McGauhey, P.H. Engineering management of water quality. McGraw-Hill Book Company, New York, 1968.

10. Joshi, S.V.; Drzal, L.T.; Mohanty, A.K.; Arora, S. Are natural fiber composites environmentally superior to glass fiber reinforced composites? Compos Part A-Appl S 2004, 35, 371-6, https://doi.org/10.1016/j.compositesa.2003.09.016.

11. Hussein, A.; Scholz, M. Treatment of artificial wastewater containing two azo textile dyes by vertical-flow constructed wetlands. Environ Sci Pollut R 2018, 25, 6870-89, https://doi.org/10.1007/s11356-017-0992-0.

12. Brik, M.; Schoeberl, P.; Chamam, B.; Braun, R.; Fuchs, W. Advanced treatment of textile wastewater towards reuse using a membrane bioreactor. Process Biochem 2006, 41, 1751-7, https://doi.org/10.1016/j.procbio.2006.03.019.

13. Buscio, V.; Crespi, M.; Gutiérrez-Bouzán, C. Sustainable dyeing of denim using indigo dye recovered with polyvinylidene difluoride ultrafiltration membranes. J Clean Prod 2015, 91, 201-7, https://doi.org/10.1016/j.jclepro.2014.12.016.

14. Couto, C.F.; Lange, L.C.; Amaral, M.C. A critical review on membrane separation processes applieremove pharmaceutically active compounds from water and wastewater. J Water Process Eng 2018, 26, 156-75, https://doi.org/10.1016/j.jwpe.2018.10.010.

15. Khatri, A.; Peerzada, M.H.; Mohsin, M.; White, M. A review on developments in dyeing cotton fabrics with reactive dyes for reducing effluent pollution. $J$ Clean Prod 2015, 87, 50-7, https://doi.org/10.1016/j.jclepro.2014.09.017.

16. Vedrenne, M.; Vasquez-Medrano, R.; Prato-Garcia, D.; Frontana-Uribe, B.A.; Hernandez-Esparza, M.; de Andrés, J.M. A ferrous oxalate mediated photo-Fenton system: toward an increased biodegradability of indigo dyed wastewaters. J Hazard Mater 2012, 243, 292-301, https://doi.org/10.1016/j.jhazmat.2012.10.032.

17. Morali, E.K.; Uzal, N.; Yetis, U. Ozonation pre and post-treatment of denim textile mill effluents: Effect of cleaner production measures. J Clean Prod 2016, 137, 1-9, https://doi.org/10.1016/j.jclepro.2016.07.059.

18. de Oliveira Neto, G.C.; Correia, J.M.F.; Silva, P.C.; de Oliveira Sanches, A.G.; Lucato, W.C. Cleaner Production in the textile industry and its relationship to sustainable development goals. Journal of cleaner production 2019, 228, 1514-1525, https://doi.org/10.1016/j.jclepro.2019.04.334.

19. Tünay, O.; Kabdasli, I.; Eremektar, G.; Orhon, D. Color removal from textile wastewaters. Water Sci Technol 1996, 34, 9-16, https://doi.org/10.1016/S0273-1223(96)00815-3.

20. Marcucci, M.; Ciardelli, G.; Matteucci, A.; Ranieri, L.; Russo, M. Experimental campaigns on textile wastewater for reuse by means of different membrane processes. Desalination 2002, 149, 137-43, https://doi.org/10.1016/S0011-9164(02)00745-2.

21. Manu, B. Physico-chemical treatment of indigo dye wastewater. Color Technol 2007, 123, 197-202, https://doi.org/10.1111/j.1478-4408.2007.00080.x.

22. Verma, A.K.; Dash, R.R.; Bhunia, P. A review on chemical coagulation/flocculation technologies for removal of colour from textile wastewaters. $J$ Environ Manage 2012, 93, 154-68, https://doi.org/10.1016/j.jenvman.2011.09.012.

23. Aleem, M.; Cao, J.; Li, C.; Rashid, H.; Wu, Y.; Nawaz, M.I.; Abbas, M.; Akram, M.W. Coagulation-and Adsorption-Based Environmental Impact Assessment and Textile Effluent Treatment. Water, Air, \& Soil Pollution 2020, 231, https://doi.org/10.1007/s11270-020-4400-x.

24. Collivignarelli, M.C.; Abbà, A.; Miino, M.C.; Damiani, S. Treatments for color removal from wastewater: State of the art. Journal of environmental management 2019, 236, 727-745, https://doi.org/10.1016/j.jenvman.2018.11.094.

25. Rashid, R.; Shafiq, I.; Akhter, P.; Iqbal, M. J.; Hussain, M. A state-of-the-art review on wastewater treatment techniques: the effectiveness of adsorption method. Environmental Science and Pollution Research 2021, 28, 1-17, https://doi.org/10.1007/s11356-021-12395-x.

26. Kang, Y.W.; Hwang, K.Y. Effects of reaction conditions on the oxidation efficiency in the Fenton process. Water Res 2000, 34, 2786-90, https://doi.org/10.1016/S0043-1354(99)00388-7.

27. Meriç, S.; Kaptan, D.; Ölmez, T. Color and COD removal from wastewater containing Reactive Black 5 using Fenton's oxidation process. Chemosphere 2004, 54, 435-41, https://doi.org/10.1016/j.chemosphere.2003.08.010. 
28. Martínez-Huitle, C.A.; dos Santos, E.V.; de Araújo, D.M.; Panizza, M. Applicability of diamond electrode/anode to the electrochemical treatment of a real textile effluent. J Electroanal Chem 2012, 674, 103-7, https://doi.org/10.1016/j.jelechem.2012.02.005.

29. Wang, Y.; Shen, Z.; Chen, X. Effects of experimental parameters on 2, 4-dichlorphenol degradation over Er-chitosan-PbO2 electrode. J Hazard Mater 2010, https://doi.org/10.1016/j.jhazmat.2010.02.018.

30. Karthikeyan, S.; Titus, A.; Gnanamani, A.; Mandal, A.B.; Sekaran, G. Treatment of textile wastewater by homogeneous and heterogeneous Fenton oxidation processes. Desalination 2011, 281, 438-45, https://doi.org/10.1016/j.desal.2011.08.019.

31. Soares, P.A.; Batalha, M.; Souza, S.M.; Boaventura, R.A.; Vilar, V.J. Enhancement of a solar photo-Fenton reaction with ferric-organic ligands for the treatment of acrylic-textile dyeing wastewater. J Environ Manage 2015, 152, 120-31, https://doi.org/10.1016/j.jenvman.2015.01.032.

32. Bello, M.M.; Raman, A.A.A.; Asghar, A. Activated carbon as carrier in fluidized bed reactor for Fenton oxidation of recalcitrant dye: Oxidation-adsorption synergy and surface interaction. Journal of Water Process Engineering 2020, 33, https://doi.org/10.1016/j.jwpe.2019.101001.

33. Brillas, E.; Garcia-Segura, S. Benchmarking recent advances and innovative technology approaches of Fenton, photo-Fenton, electro-Fenton, and related processes: A review on the relevance of phenol as model molecule. Separation and Purification Technology 2020, 237, https://doi.org/10.1016/j.seppur.2019.116337.

34. Wang, X.; Zhang, X.; Zhang, Y.; Wang, Y.; Sun, S.P.; Wu, W.D.; Wu, Z. Nanostructured semiconductor supported iron catalysts for heterogeneous photo-Fenton oxidation: a review. Journal of Materials Chemistry A 2020, 8, 15513-15546, https://doi.org/10.1039/D0TA04541A.

35. Mondal, P.; Baksi, S.; Bose, D. Study of environmental issues in textile industries and recent wastewater treatment technology. WSN 2017, 61(2), 98-109.

36. Sahinkaya, E.; Uzal, N.; Yetis, U.; Dilek, F.B. Biological treatment and nanofiltration of denim textile wastewater for reuse. J Hazard Mater 2008, 153, 1142-8, https://doi.org/10.1016/j.jhazmat.2007.09.072.

37. Yigit, N.O.; Uzal, N.; Koseoglu, H.; Harman, I.; Yukseler, H.; Yetis, U.; Civelekoglu, G.; Kitis, M. Treatment of a denim producing textile industry wastewater using pilot-scale membrane bioreactor. Desalination 2009, 240, 143-50, https://doi.org/10.1016/j.desal.2007.11.071.

38. Sarayu, K.; Sandhya, S. Current technologies for biological treatment of textile wastewater-a review. Appl Biochem Biotech 2012, 167, 645-61, https://doi.org/10.1007/s12010-012-9716-6.

39. Paździor, K.; Bilińska, L.; Ledakowicz, S. A review of the existing and emerging technologies in the combination of AOPs and biological processes in industrial textile wastewater treatment. Chemical Engineering Journal 2019, 376, https://doi.org/10.1016/j.cej.2018.12.057.

40. Kim, S.; Park, C.; Kim, T.H.; Lee, J.; Kim, S.W. COD reduction and decolorization of textile effluent using a combined process. J Biosci Bioeng 2003, 95, 102-5, https://doi.org/10.1016/S1389-1723(03)80156-1.

41. GilPavas, E.; Dobrosz-Gómez, I.; Gómez-García, M.Á. Efficient treatment for textile wastewater through sequential electrocoagulation, electrochemical oxidation and adsorption processes: Optimization and toxicity assessment. Journal of Electroanalytical Chemistry 2020, 878, https://doi.org/10.1016/j.jelechem.2020.114578.

42. Ciardelli, G.; Corsi, L.; Marcucci, M. Membrane separation for wastewater reuse in the textile industry. Resour Conserv Recy 2001, 31,189-97, https://doi.org/10.1016/S0921-3449(00)00079-3.

43. Marcucci, M.; Nosenzo, G.; Capannelli, G.; Ciabatti, I.; Corrieri, D.; Ciardelli, G. Treatment and reuse of textile effluents based on new ultrafiltration and other membrane technologies. Desalination 2001, 138, 7582, https://doi.org/10.1016/S0011-9164(01)00247-8.

44. Buthiyappan, A.; Raja Ehsan Shah, R.S.S.; Asghar, A.; Abdul Raman, A.A.; Daud, M.A.W.; Ibrahim, S.; Tezel, F.H. Textile wastewater treatment efficiency by Fenton oxidation with integration of membrane separation system. Chemical Engineering Communications 2019, 206, 541-557, https://doi.org/10.1080/00986445.2018.1508021.

45. Tkaczyk, A.; Mitrowska, K.; Posyniak, A. Synthetic organic dyes as contaminants of the aquatic environment and their implications for ecosystems: a review. Science of The Total Environment 2020, 717 , https://doi.org/10.1016/j.scitotenv.2020.137222.

46. Soares, P.A.; Silva, T.F.; Manenti, D.R.; Souza, S.M.; Boaventura, R.A.; Vilar, V.J. Insights into real cottontextile dyeing wastewater treatment using solar advanced oxidation processes. Environ Sci Pollut $R$ 2014, 21, 932-45, https://doi.org/10.1007/s11356-013-1934-0.

47. Aksu, O.; Yildirim, N.C.; Yildirim, N.; Danabas, D.; Danabas, S. Biochemical response of crayfish Astacus leptodactylus exposed to textile wastewater treated by indigenous white rot fungus Coriolus versicolor. Environ Sci Pollut R 2015, 22, 2987-93, https://doi.org/10.1007/s11356-014-3550-z.

48. Wanassi, B.; Hariz, I.B.; Ghimbeu, C.M.; Vaulot, C.; Hassen, M.B.; Jeguirim, M. Carbonaceous adsorbents derived from textile cotton waste for the removal of Alizarin $\mathrm{S}$ dye from aqueous effluent: kinetic and equilibrium studies. Environ Sci Pollut R 2017, 24, 10041-55, https://doi.org/10.1007/s11356-017-8410-1.

49. Orhon, D.; Germirli Babuna, F.; Insel, G. Characterization and modelling of denim-processing wastewaters for activated sludge. J Chem Tech Biotech 2001, 76, 919-931, https://doi.org/10.1002/jctb.462. 
50. Yukseler, H.; Uzal, N.; Sahinkaya, E.; Kitis, M.; Dilek, F.B.; Yetis, U. Analysis of the best available techniques for wastewaters from a denim manufacturing textile mill. J Enviro Manage 2017, 203, 11181125, https://doi.org/10.1016/j.jenvman.2017.03.041.

51. Samsami, S.; Mohamadi, M.; Sarrafzadeh, M.H.; Rene, E.R.; Firoozbahr, M. Recent advances in the treatment of dye-containing wastewater from textile industries: Overview and perspectives. Process Safety and Environmental Protection 2020, 143, 138-163, https://doi.org/10.1016/j.psep.2020.05.034.

52. Hooshmand, M.; Sözen, S.; Sensoy, H.A.; Orday, N.; Yağc1, N.; Orhon, D. Color and pumice stone problems in denim processing: Removal potential bu integrated physical-chemical treatment. J Chem Tech Biotech 2020, 95, 142-150, https://doi.org/10.1002/jctb.6216.

53. Sözen, S.; Ölmez-Hanc1, T.; Hooshmand, M.; Orhon, D. Fenton oxidation for effective removal of color and organic matter from denim cotton wastewater without biological treatment. Environ Chem Lett 2020, 18, 207-213, https://doi.org/10.1007/s10311-019-00923-8.

54. International Ozone Association. Iodometric method for the determination of ozone in a process gas. Revised Standardized Procedure 001/96, Paris, 1996.

55. Oguz, E.; Keskinler, B.; Celik, C.; Çelik, Z. Determination of the optimum conditions in the removal of Bomaplex Red CR-L dye from the textile wastewater using O3, H2O2, HCO3- and PAC. J Hazard Mater 2006, 131, 66-72, https://doi.org/10.1016/j.jhazmat.2005.09.015.

56. Federation, W.E. American Public Health Association. Standard methods for the examination of water and wastewater, American Public Health Association (APHA): Washington, DC, USA, 2005.

57. International Standards Organization (ISO). Water Quality-Determination of the Chemical Oxygen DemandISO 6060, 1989.

58. Kayser, R. Sewage treatment with nitrogen and phosphorus elimination. In: Handbook of Water Supply and Sewage Technology. 3rd Edition, Vulkan Publishing Company: Essen, Germany, 1989.

59. Tas, D.O.; Karahan, Ö.; Övez, S.; Orhon, D.; Spanjers, H. Biodegradability and denitrification potential of settleable chemical oxygen demand in domestic wastewater. Water Environ Res 2009, 81, 715-27, https://doi.org/10.2175/106143009X425942.

60. Oguz, E.; Keskinler, B. Removal of colour and COD from synthetic textile wastewaters using O3, PAC, H2O2 and HCO3-. J Hazard Mater 2008, 151, 753-60, https://doi.org/10.1016/j.jhazmat.2007.06.045. 


\section{Supplementary materials}

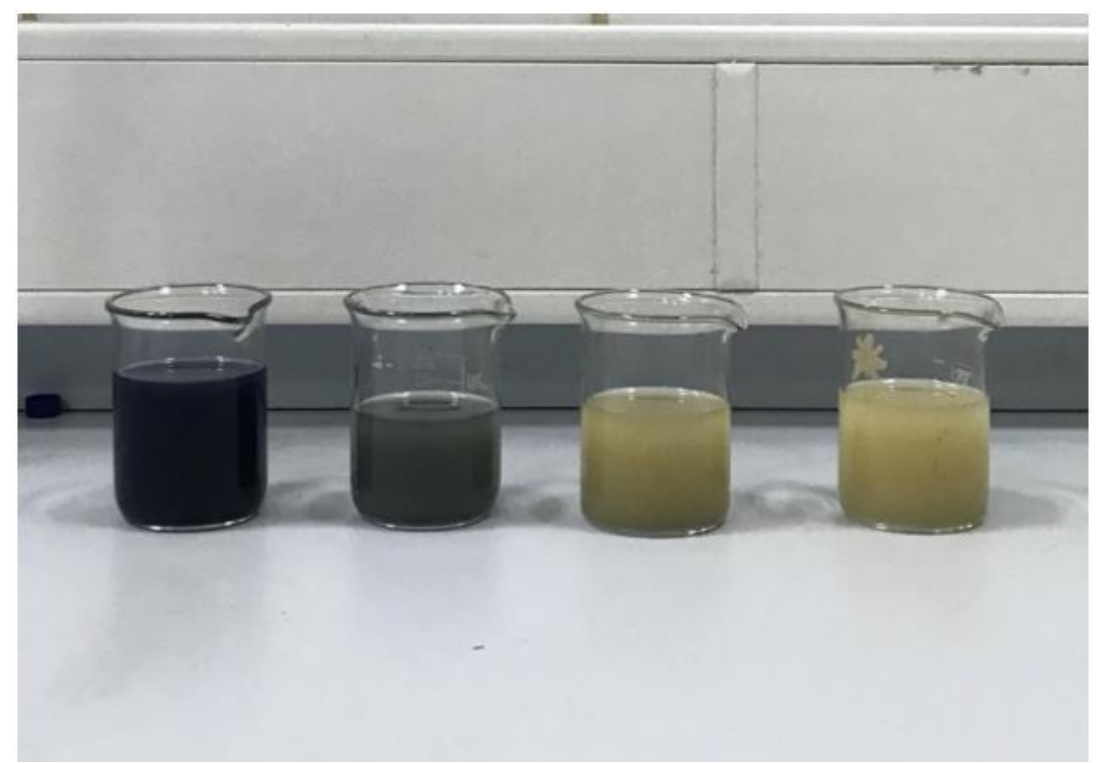

Figure S1. Visual display of remaining color in the mixture of segregated sample after ozone treatment.

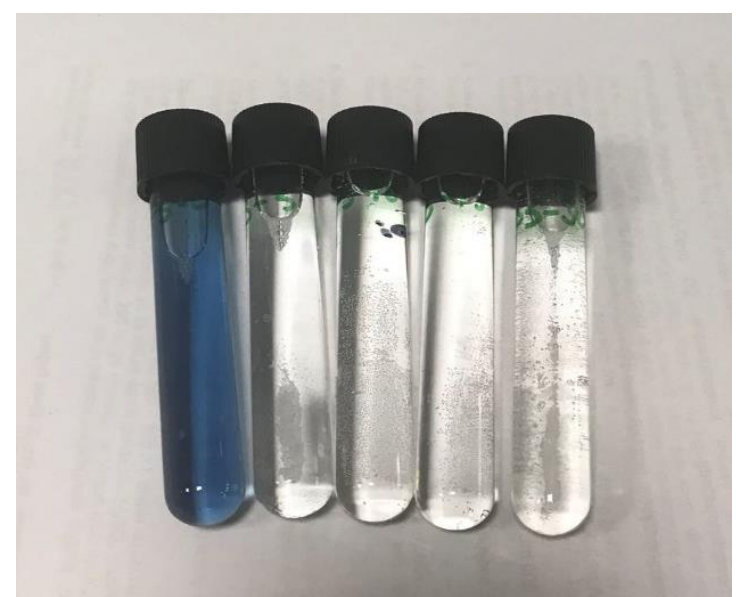

Figure S2. Visual display of color disappearance with Fenton oxidation at 10 minutes. 